\title{
Regulatory Resources and Emotional States in Overcoming Difficulties of Self-organization During Lockdown
}

\author{
V. I. Morosanova ${ }^{1}$ I. N. Bondarenko ${ }^{1}$ (1) N. G. Kondratyuk ${ }^{1}$
}

Received: 18 August 2020/Accepted: 1 June 2021 / Published online: 18 July 2021

(C) National Academy of Psychology (NAOP) India 2021

\begin{abstract}
The research aimed to study the characteristics of the joint influence of conscious self-regulation and emotional states on life self-organization during a lockdown and identify the factors that contribute to overcoming emerging difficulties. It was conducted online, using the block site builder Tilda Publishing (tilda.ws) and a Google Forms survey administration application. The empirical structural model of regulatory and emotional predictors of self-organization during the lockdown shows that conscious self-regulation in conditions of imposed self-isolation acts as a universal resource for successful selforganization, managing the difficulties of reorganizing one's life, and coping with the anxiety of uncertainty. Positive and negative emotional states affect these processes differently. Optimism significantly contributes to conscious self-regulation, indirectly supporting successful self-organization of life and preventing the development of accomplishments. We identified the regulatory factor ("Cito-resource of self-regulation"), which plays a crucial role in overcoming self-organization difficulties during a lockdown. This factor is represented by the regulatory indicators of modeling significant conditions for achieving goals and reliability. The higher its development, the easier it is for a person to manage the difficulties of self-organization and cope with anxiety caused by uncertainty.
\end{abstract}

I. N. Bondarenko

pondi@inbox.ru

V. I. Morosanova

morosanova@mail.ru

N. G. Kondratyuk

n.kondratyuk@gmail.com

1 Psychological Institute of the Russian Academy of Education, Moscow, Russia
Conscious self-regulation acts as a resource for the selforganization of human life in the lockdown conditions, providing a flexible adjustment of behavior to new challenges. High self-regulation and successful self-organization, acting as a resource of stress protection, increases the ability to maintain health. An optimistic attitude, in its turn, positively affects the conscious self-regulation of human activity.

Keywords Coronavirus COVID-19 · Lockdown ·

Self-regulation $\cdot$ Self-organization $\cdot$ states

\section{Introduction}

During the COVID-19 pandemic, people have faced external threats of the scale obviously exceeding the previously formed adaptation possibilities. Fear for one's and relatives' health, an avalanche of contradictory information in the media, restrictions imposed on mobility and direct communication with people-everybody found themselves in a situation of unprecedented changes in the usual way of life in all spheres. According to the first studies on the subject, living in self-isolation induces negative emotional states of varying severity in the population: anxiety, depression, confusion, hopelessness, panic, suicidal thoughts, etc. (Guan et al., 2020; Montemurro, 2020; Peng, et al., 2020). In the lockdown conditions, many people face the need to cope with anxiety, to meet previously assumed commitments, to take care of their health and others' safety by means of managing their routine, educational, and professional lives. In these circumstances, the issues of self-regulation of achieving goals in the above-mentioned life domains acquire paramount importance. However, due to the uncertainty of the pandemic timing, the human self- 
regulation system itself is vulnerable. Baumeister (1998) stressed that exerting your willpower drains your overall reserve of self-regulation. It was shown that self-regulation is a limited resource. Self-control processes exhaust it for a while (an effect of "ego-depletion.") The capacity for selfregulation differs between individuals and depends on situational factors (Hoyle, 2006). Traditionally, researchers had been studying the structure, characteristics, and effects of self-regulation on the examples of diverse but everyday routine activities, e.g., self-regulated learning (SRL) (Baumeister \& Vohs, 2004; Boekaerts \& Cascallar, ; Zimmerman \& Schunk, 2001). Research on selfregulation in situations of uncertainty and high emotional stress is scarce, and is currently extremely relevant.

In this study, we used the approach to conscious selfregulation developed by V. Morosanova. This approach defines conscious self-regulation as a system of the regulatory-cognitive processes (planning goals, modeling significant conditions for their achievement, programming actions, evaluating results) and regulatory-intrapersonal features (flexibility, reliability, perseverance, responsibility) (Morosanova, 2014). This system mobilizes all other types of individual resources to achieve a set goal. Essentially, it is a resource, which availability and development significantly influence success, reliability, productivity, and the final results of goal achievement in various life situations (Morosanova, 2017).

During a pandemic-induced lockdown, self-organization of behavior acquires specific features. In conditions of imposed self-isolation at home, it is related to the purposeful lifestyle changes per professional and educational activities, allowing to maintain a positive emotional state. Practically few research pieces are using the concept of "self-organization" in a psychological or pedagogical context. It often appears as a frame of research on developmental processes (Lewis \& Granic, 2000). This concept is used primarily in medical, chemical, and physiological research. Psychologists consider conceptually similar phenomena related to self-processes, primarily self-control (Kuhnle et al., 2010; Kuhnle et al., 2012; Grund \& Carstens, 2019), defined as an ability to suppress irrelevant impulses, thoughts, and behaviors to achieve a goal (Baumeister et al., 2006). High self-organization allows a person to solve the tasks faster and with less effort, overcome difficulties more effectively, display initiative, and take responsibility. It also provides readiness to adjust one's activities in case of failure (Kostromina, 2010). However, what is the structure of self-organization of ordinary people, who instantly got into the VUCA-world (volatility, uncertainty, complexity, ambiguity)—an environment in which only top-managers were assumed to feel confident so far? To answer this question, we developed a special questionnaire and tested it on a sample of more than
1500 people. It turned out that the structure of self-organization during the pandemic includes three factors: "success in the self-organization of life," "difficulties in the self-organization of life," and "difficulties in accepting uncertainty" (for a more detailed description of the questionnaire, see the Methods section).

A high level of uncertainty affects a person's psychoemotional state during the period of self-isolation, which can lead to cumulative stress. As Kumar and Somani (2020) point out, even an abundance of useful information, such as tips and recommendations, can cause adverse reactions of anxiety, fright, depression, and obsessivecompulsive disorder. However, it is not the uncertainty itself that causes anxiety, but its subjective assessment and several related factors. Among these factors, the researchers pay special attention to emotional experiences. Emotional phenomena related to professional and educational activities are among the top research issues during the last 20 years: emotional burnout (Vodopyanova \& Starchenkova, 2008; Maslach \& Jackson, 1981), emotional intelligence (Mayer et al., 2008; Lyusin \& Ushakov, 2009), Pulkkinen's model of cognitive regulation (Puustinen \& Pulkkinen, 2001), Gross' model of emotional regulation (Gross \& Jazaieri, 2014), the model of cognitive strategies for regulating emotions by Garnefski et al. (2002), etc.

In the present study, we were interested not only and not so much in the specific emotions experienced by the respondents during the lockdown period (they are predictable), but also in their understanding of their state, ways of coping with negative experiences, assessment of their abilities to overcome difficulties, etc. For this study, we have developed a special questionnaire. It consists of two parts: The first part includes assessing the occurance frequence of positive and negative emotions. The second part inquires about the feelings, activities and plans of the respondents (for more details, see the Methods section). In a COVID-19 pandemic, according to Buheji et al. (2020) stress occurs when a person lacks the resources to adapt to a changed situation.

Conscious self-regulation of achieving goals can serve as one of these resources. It is responsible for the states and processes linked to the regulation of stress, moods, thoughts, attention, emotions, and impulses (hunger, aggression, sexual arousal) (Gross, 2007). Thus, self-regulation is often associated with emotional regulation (Achtziger et al., 2008; Ochner \& Gross, 2005; Gross \& John, 2003), emphasizing the emotional aspect of selfregulation.

The researchers proposed several models of Emotion Self-regulation. Some of them focus on emotions (Sheppes \& Gross, 2011; Gross, 2015), while others focus on regulation (Carver \& Scheier, 1998; Gallo, et al., 2009). We agree with S. Koole, who insisted that studying how self- 
regulation of goal achievement interacts with emotion regulation would help understand both processes. In particular, these studies would reveal how people regulate their emotional state in situations that generate strong negative emotions (Koole et al., 2015).

This approach allows for suggesting:

Hypothesis 1 The higher the conscious self-regulation of achieving goals, the more successfully a person organizes his life in a lockdown situation.

Hypothesis 2 Optimism, as a state, makes a positive contribution to successful self-organization through conscious self-regulation.

Hypothesis 3 Negative emotional states increase the difficulties of self-organization, while conscious self-regulation helps to overcome them.

\section{Methods}

\section{Participants}

The study involved 229 people, mostly students of the Plekhanov Institute in Moscow (179 women -78\%), and the age of the respondents ranged from 18 to 60 years $(M=$ 21.8, $\mathrm{SD}=4.9$ ).

\section{Procedure}

The survey took place during the lockdown period from late April to early June, 2020, in online format, using the block site builder Tilda Publishing (tilda.ws) and Google Forms survey administration application.

\section{Measures}

1. "Morosanova's Self-regulation profile questionnaire2020" (Morosanova \& Kondratyuk 2020) evaluates the level SR and its individual characteristics consistently manifesting in various types of voluntary activity and life situations. The 28-item questionnaire includes seven scales, among which 4 scales assess regulatory-cognitive processes (planning of goals, modeling of significant conditions for achieving goals, programming of actions, results evaluation) and 3 scales evaluate regulatory-intrapersonal features (flexibility, perseverance, reliability). There is an integrative indicator "the General level of Conscious SelfRegulation" summing up the scores on seven scales, which characterizes development of self-regulation as a whole. Participants evaluate their agreement with statements on a 5-point Likert scale, which ranged from $1=$ "strongly disagree" to $5=$ "strongly agree." Cronbach's alphas for the scales in the present study ranged from 0.60 to 0.83 .

2. Author's ad hoc questionnaire "Self-organization of life during a lockdown." The questionnaire consists of 16 items and includes three scales: "Success in selforganization of life" (e.g., "The productivity of my work in the new conditions has not changed"); "Difficulties in self-organization of life" (e.g., "The need for online communication in the process of studying/working made me tired more than usual classroom/office environment"); and "Difficulties in accepting uncertainty" (e.g., "Because of the uncertainty, when all this ends, the long-term planning has lost any sense for me"). The General index of selforganization of life is calculated as the total indicator of all the questionnaire items. The scales "Difficulties in self-organization of life" and "Difficulties in accepting uncertainty" are reverse. We used a 5-point Likert scale from 1 (No, completely disagree) to 5 (Yes, completely agree). The 3-factor solution (45.71\% variance) is confirmed by exploratory factor analysis (principal component method, varimax-rotation). Cronbach's $\alpha$ ranges from .67 to. 81 .

3. Author's ad hoc questionnaire "Emotional states in conditions of self-isolation." The questionnaire consists of 11 statements rated on a 7-point Likert scale from 1 (No, completely disagree) to 7 (Yes, completely agree). The respondents are also asked to rate how often they experience the listed emotions over the specified period. Exploratory factor analysis identified 5 factors explaining more than $50 \%$ of the variance (principal component method, varimax-rotation). Table 1 contains descriptions and examples of the statements, their descriptive statistics, and Cronbach's $\alpha$.

\section{Results}

Table 2 contains descriptive statistics and correlations of SR parameters with emotional states.

Correlation analysis showed a large number of significant relationships between the indicators of conscious selfregulation and emotional states. Optimism is highly correlated with several SR processes (planning, programming, results evaluation), with regulatory features (flexibility, perseverance), and the general level of SR. The higher the SR development, the lower the negative emotions, hopelessness, and emotional exhaustion, and the easier it is to cope with difficulties of self-organization and uncertainty experience. An impressive result was obtained for the 
Table 1 Scales description, statement examples, descriptive statistics and Cronbach's $\alpha$ of "emotional states in conditions of self-isolation"

Emotional states in conditions of self-isolation

\begin{tabular}{|c|c|c|c|c|}
\hline Scale & Description & Example & $M \pm \sigma$ & $\alpha$ \\
\hline Optimism & $\begin{array}{l}\text { Assesses the ability to use the new advantages and perceive } \\
\text { them as a support for further development }\end{array}$ & $\begin{array}{l}\text { «I manage to do a lot during a day, and it fills } \\
\text { me with hope that everything will be fine» }\end{array}$ & $3.21 \pm .78$ & .814 \\
\hline $\begin{array}{l}\text { Negative } \\
\text { emotions }\end{array}$ & Assesses the severity of negative emotions & Fear, anxiety, grief, anger, guilt & $2.18 \pm .74$ & .810 \\
\hline $\begin{array}{l}\text { Emotional } \\
\text { exhaustion }\end{array}$ & Assesses the level of emotional exhaustion & $\begin{array}{l}\text { «I feel indifference and loss of interest in many } \\
\text { things that pleased me before»; }\end{array}$ & $2.32 \pm .80$ & .760 \\
\hline Hopelessness & Assesses the level of hopelessness & Boredom, yearning & $2.89 \pm 1.14$ & .804 \\
\hline $\begin{array}{l}\text { Self-analysis } \\
\text { of the state }\end{array}$ & $\begin{array}{l}\text { Assesses the attention to one's own emotional state and } \\
\text { perceived connections between difficulties in self- } \\
\text { organization and body manifestations, relations to } \\
\text { relatives and colleagues, daily routines, etc. }\end{array}$ & $\begin{array}{l}\text { «Do you know which of your reactions signal } \\
\text { that you are under stress (for example, } \\
\text { anxiety, trembling, etc.) » }\end{array}$ & $2.99 \pm .71$ & .479 \\
\hline
\end{tabular}

$A-$ Cronbach's $\alpha$.

Table 2 Descriptive statistics and correlations between conscious self-regulation and emotional states

\begin{tabular}{|c|c|c|c|c|c|c|c|c|c|c|c|c|c|c|c|}
\hline & & \multirow[t]{2}{*}{$M \pm \sigma$} & \multicolumn{9}{|c|}{ Conscious self-regulation } & \multicolumn{4}{|c|}{ Emotional state } \\
\hline & & & 1 & 2 & 3 & 4 & 5 & 6 & 7 & 8 & 9 & 10 & 11 & 12 & 13 \\
\hline 1 & Planning & $12.60 \pm 3.50$ & 1 & & & & & & & & & & & & \\
\hline 2 & Programming & $14.58 \pm 2.88$ & .31 & 1 & & & & & & & & & & & \\
\hline 3 & Modeling & $12.72 \pm 2.77$ & .37 & .13 & 1 & & & & & & & & & & \\
\hline 4 & Results evaluation & $12.27 \pm 3.61$ & .36 & .37 & .20 & 1 & & & & & & & & & \\
\hline 5 & Flexibility & $13.46 \pm 3.05$ & .18 & .22 & .15 & & 1 & & & & & & & & \\
\hline 6 & Reliability & $9.72 \pm 3.40$ & & -.16 & .43 & & & 1 & & & & & & & \\
\hline 7 & Perseverance & $14.57 \pm 3,15$ & .26 & .45 & .27 & .23 & .42 & & 1 & & & & & & \\
\hline 8 & General level of SR & $89.92 \pm 12.60$ & .68 & .57 & .63 & .59 & .50 & .34 & .64 & 1 & & & & & \\
\hline 9 & Optimism & $3.21 \pm 0.78$ & .29 & .33 & & .25 & .38 & & .44 & .43 & 1 & & & & \\
\hline 10 & Negative emotions & $2.18 \pm 0.74$ & & . & -.33 & & -.15 & -.26 & -.21 & -.30 & & 1 & & & \\
\hline 11 & Emotional exhaustion & $2.32 \pm 0.80$ & -.23 & & -.17 & & -.18 & -.16 & -.24 & -.18 & -.27 & .47 & 1 & & \\
\hline 12 & Hopelessness & $2.89 \pm 1.14$ & -.24 & -.13 & -.25 & -.21 & & -.21 & & -.31 & -.15 & .45 & .34 & 1 & \\
\hline 13 & Self-analysis of the state & $3.00 \pm .71$ & & & -.20 & .21 & & -.34 & & & & .31 & .41 & .19 & 1 \\
\hline
\end{tabular}

Note. $p<0.05, \mathbf{p}<\mathbf{0 . 0 1}$.

indicator "Self-analysis of the state." The more attention people pay to their states, the weaker is their ability to organize their activities productively during a lockdown. The state's self-analysis also has a positive relationship with the regulatory process of Results evaluation since they are functionally similar, although they differ in the rationality of assessments. This indicator also demonstrates a negative correlation with modeling. The subjective model of significant conditions in the conscious SR system contains information about a set of external and internal conditions. It is impossible to perform successfully without taking into account and controlling them. With a reduced level of modeling, the person is "turned off" from the situation, which does not reduce anxiety or achieve goals.
Recent research on the regulatory features of people occupied in high-risk professions revealed that modeling significant conditions is one of the essential prerequisites for effective action in an unknown, stressful, often rapidly changing work situation (Morosanova et al., 2020; Morosanova, 2017).

Correlation analysis also revealed significant relationships between the indicators of SR and self-organization (Table 3), as well as between emotional states and selforganization (Table 4).

As expected, the success of self-organization positively correlates with optimism and negatively-with emotional exhaustion and hopelessness. The difficulties of self-organization show the opposite patterns. The higher the fears 
Table 3 Correlations between self-regulation and self-organization

\begin{tabular}{|c|c|c|c|c|}
\hline \multirow[t]{2}{*}{ Variable } & \multicolumn{4}{|l|}{ Self-organization } \\
\hline & $\begin{array}{l}\text { Success in self- } \\
\text { organization }\end{array}$ & $\begin{array}{l}\text { Difficulties in self- } \\
\text { organization }\end{array}$ & $\begin{array}{l}\text { Difficulties in accepting } \\
\text { uncertainty }\end{array}$ & $\begin{array}{l}\text { General index of self- } \\
\text { organization }\end{array}$ \\
\hline Planning & $.266 * *$ & $-.211 * *$ & $-.297 * *$ & $.313 * *$ \\
\hline Programming & $.354 * *$ & $-.201 * *$ & & $.246^{* *}$ \\
\hline Modeling & & $-.192 * *$ & $-.241 * *$ & $.195 * *$ \\
\hline Results evaluation & $.258^{* *}$ & & & $.170^{*}$ \\
\hline Flexibility & $.311 * *$ & $-.318 * *$ & $-.171 *$ & $.328 * *$ \\
\hline Perseverance & $.360 * *$ & & & $.243 * *$ \\
\hline Reliability & & $-.147 *$ & $-.217 * *$ & \\
\hline $\begin{array}{l}\text { General level of } \\
\text { SR }\end{array}$ & $.407 * *$ & $-.311 * *$ & $-.265^{* *}$ & $.406 * *$ \\
\hline
\end{tabular}

$* * \rho \leq .01, * \rho \leq .05$.

Table 4 Correlations between self-organization and emotional states

\begin{tabular}{|c|c|c|c|c|c|c|}
\hline \multirow[t]{2}{*}{ Variable } & \multirow[t]{2}{*}{$M \pm \sigma$} & \multicolumn{5}{|c|}{ Emotional states } \\
\hline & & Optimism & $\begin{array}{l}\text { Negative } \\
\text { emotions }\end{array}$ & $\begin{array}{l}\text { Emotional } \\
\text { exhaustion }\end{array}$ & Hopelessness & $\begin{array}{l}\text { Self-analysis of the } \\
\text { state }\end{array}$ \\
\hline Success in self-organization & $3.11 \pm .97$ & $0.452 * *$ & & $-0.183^{* *}$ & $-0.195 * *$ & \\
\hline Difficulties in self-organization & $1.59 \pm 1.01$ & $-0.263 * *$ & & $0.277 * *$ & $0.215^{* *}$ & $0.150^{*}$ \\
\hline $\begin{array}{l}\text { Difficulties in accepting } \\
\text { uncertainty }\end{array}$ & $3.10 \pm .93$ & $-0.169 *$ & $0.142 *$ & $0.357 * *$ & $0.209^{* *}$ & \\
\hline General index of self-organization & $1.59 \pm 2.30$ & $0.366^{* *}$ & & $-0.340^{* *}$ & $-0.249 * *$ & \\
\hline
\end{tabular}

$* * \rho \leq .01, * \rho \leq .05$.

associated with uncertainty-the higher the negative emotional states (TABLE 4).

The mean comparison of groups with high and low selforganization demonstrates significant differences in almost all the analyzed indicators, except for the severity of negative emotions (Fig. 1). The general level of conscious selfregulation also significantly differs in the two groups.

The results described above suggest that building a model reflecting the impact of conscious self-regulation and emotional state on self-organization would allow for identifying significant predictors of successful self-organization and resources to overcome its difficulties.

\section{Structural Model of Regulatory and Emotional Predictors of Life Self-organization During a Lockdown}

When building the structural model, we relied on the data of correlation analysis. Self-organization indicators were used as dependent variables: success in life self-organization, difficulties in life self-organization, and difficulties in accepting uncertainty. The independent variables were indicators of the conscious SR development and indicators of the emotional states. We didn't use the negative emotion indicator in the model since no significant correlations were obtained. Also, it didn't reveal significant differences in groups with high and low self-organization. Two latent factors represent conscious self-regulation. The first one is "self-regulation" including five regulatory indicators (planning, programming, evaluation of results, flexibility, and independence). The second one- "Cito-resource of self-regulation" is represented by the modeling process and the regulatory feature of reliability.

The structural equation modeling (SEM) results using the AMOS 23 computer program confirmed this model's statistical validity. To evaluate the model, we used the following consent indices and their valid values for accepting the model as corresponding to the data: Chisquare/df $<2$; p $>0.05$; GFI $>0.95$; CFI $>0.95$; RMSEA $<0.05$; PCLOSE not lower than 0.1 (Fig. 2).

Chi-square/df $=1.922 ; \quad p=0.014 ; \quad$ GFI $=0.968$; $\mathrm{CFI}=0.957 ; \mathrm{RMSEA}=0.41 ; \mathrm{PCLOSE}=0.770$

The model demonstrates the specifics of the determination of self-organization components by the regulatory 


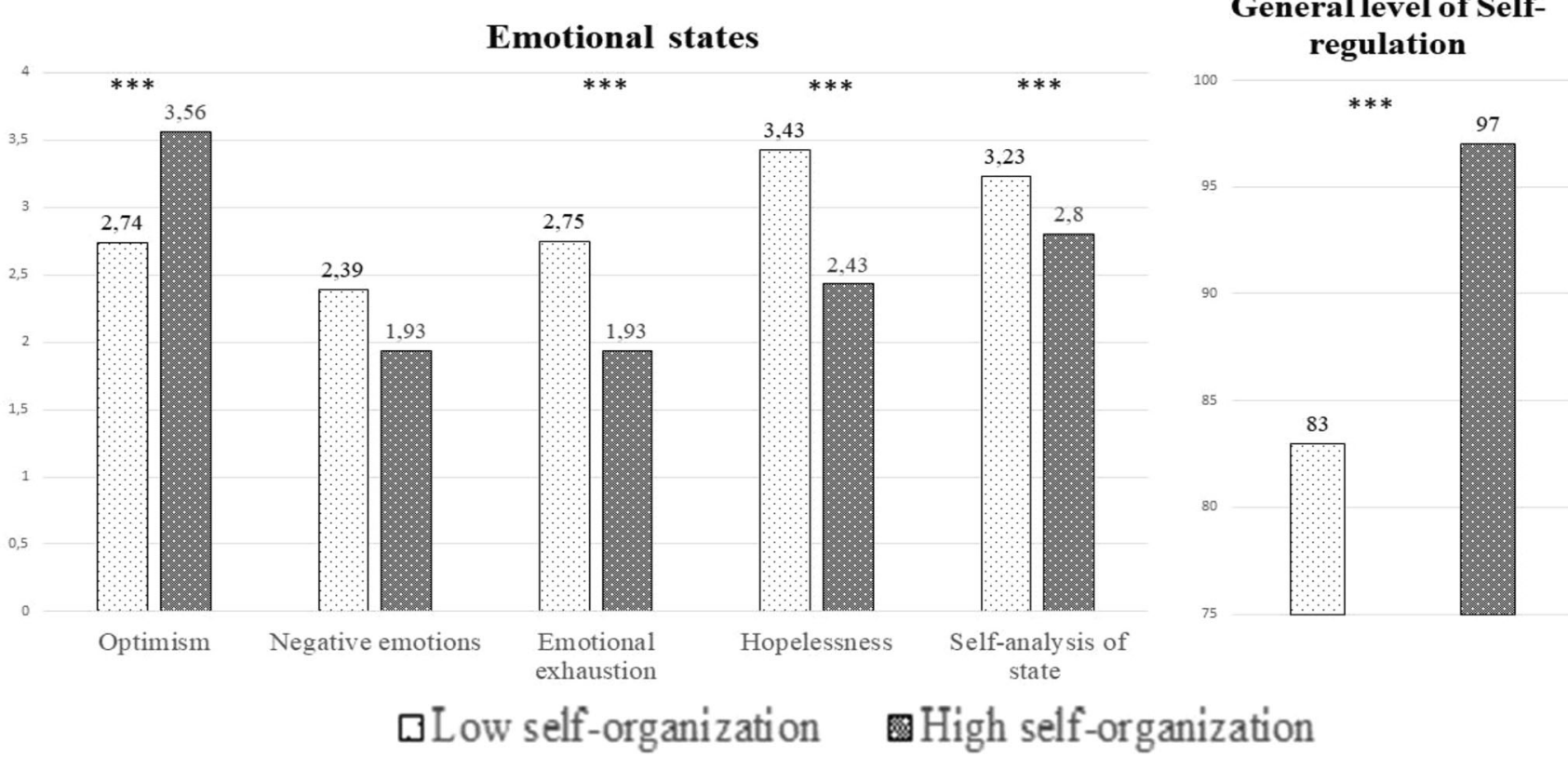

Fig.1 Mean comparisons of groups with high and low self-organization regarding emotional states and self-regulation

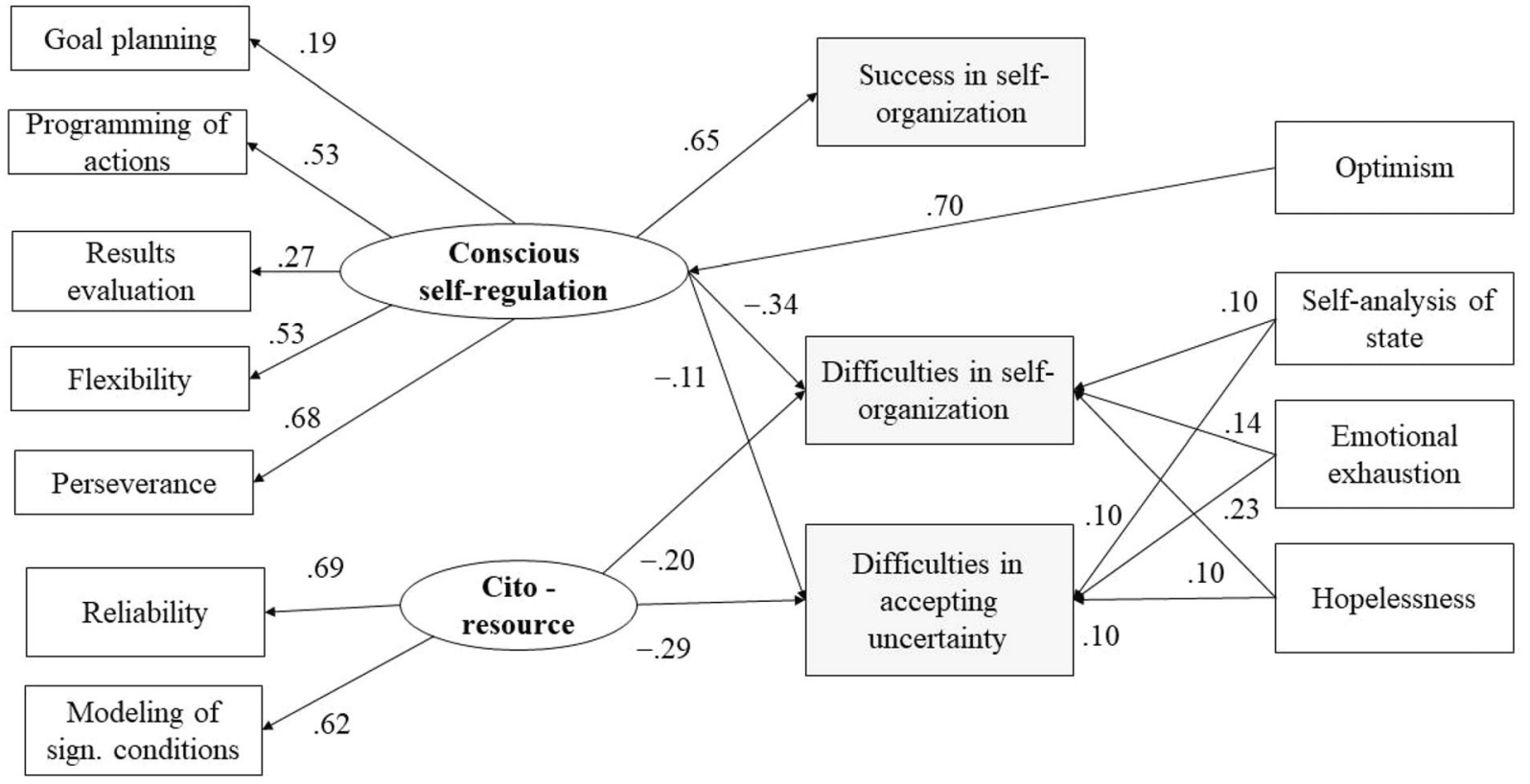

Chi-square $/ \mathrm{df}=1.922 ; \mathrm{p}=0.014 ; \mathrm{GFI}=0.968 ; \mathrm{CFI}=0.957 ; \mathrm{RMSEA}=0.41 ; \mathrm{PCLOSE}=0.770$

Fig. 2. Structural model of regulatory and emotional predictors of life self-organization during a lockdown

predictors of cognitive and emotional levels. Conscious self-regulation makes a direct contribution to successful self-organization of life $(b=.65)$. The higher the SR, the lower the difficulties in self-organization of life $(b=-.34)$ and the difficulties in accepting uncertainty $(b=-.11)$.
The model demonstrates the determination of self-organization components by the regulatory predictors of cognitive and emotional levels. Conscious self-regulation makes a direct contribution to successful self-organization of life $(b=.65)$. The higher the SR, the lower the 
difficulties in the self-organization of life $(b=-.34)$, and the difficulties in accepting uncertainty $(b=-.11)$.

It is for the first time when we face a situation that requires the development of a particular autonomous regulatory complex aimed exclusively at overcoming the difficulties of self-organization. We called it the Cito-resource of self-regulation (from the Latin "Cito"-urgently). It is represented by the regulatory process of modeling and the regulatory feature of reliability. We do not consider it to be a coincidence. According to our earlier research into self-regulation of different types of activity, the modeling process makes a decisive contribution to the success in solving complex mathematical tasks (Morosanova et al., 2016, Fomina \& Morosanova, 2017, 2017), to the effectiveness of actions in unpredictable situations (Bondarenko et al. 2014), to the productive performance in extreme and military occupations (Morosanova et al., 2020; Morosanova, 2017). Reliability in the self-regulation system is understood as the stability in the self-organization of a person's mental and practical activity under psychologically stressful conditions (Morosanova et al., 2020). Our studies on the learning activity self-regulation revealed that in the exam situation, this property ensures reducing anxiety to an optimal level and having exam result not lower, but often higher than the average annual grade (Morosanova \& Filippova, 2019). Another research shows that with a significant complication of the professional activity conditions, insufficient development of the SR reliability complicates the performance and leads to emerging of various kinds of difficulties (Morosanova et al., 2020).

In a situation of high uncertainty and anxiety in the stressful conditions of a pandemic, modeling and reliability act as a "reserve parachute." It is not aleatory that we did not see the contribution of the latent factor "Cito-resource of self-regulation" to successful self-organization. However, we found its negative relationship with the difficulties of life self-organization $(b=-.20)$ and the difficulties in accepting uncertainty $(b=-.29)$ : the higher this factor, the less pronounced the challenges of self-organization.

Certain specifics are also observed regarding the contribution of the emotional state indicators to the self-organization of life. Optimism does not directly contribute to its success. Nevertheless, the significant contribution of optimism to the general SR level $(b=.70)$ suggests its indirect contribution to self-organization indicators, mediated by conscious SR. The positive contribution of emotional exhaustion and hopelessness to self-organization difficulties and accepting uncertainty does not need additional interpretation. However, the small but positive contribution of the "self-analysis of the emotional state" should be considered in more detail. It seems that excessive attention to one's feelings, anxieties, body manifestations, sleeping disorders, and communication changes with relatives or friends (this is the content of this factor) does not contribute to successful self-organization but slightly weakens it.

We found no gender differences in self-regulation and self-organization. This result was not unexpected for us, given that the universal structure of conscious self-regulation does not imply any gender-based differences since its development is determined primarily by personality characteristics. This conclusion is likely true concerning the self-organization phenomenon, but this aspect has yet to be investigated.

We obtained some differences in the self-analysis of the state scale when examining emotional states in conditions of self-isolation. Women turned out to be more inclined to analyze their condition. These differences did not significantly affect the study results, so we decided not to include the gender differences clause in the article.

\section{Discussion}

The research results demonstrated that in conditions of imposed self-isolation during a pandemic, we can observe emerging relationships between a person's conscious selfregulation and his life self-organization accompanied with particular emotional states. An analysis of these relationships allows us to make a univocal conclusion that conscious self-regulation is a crucial element in the system of adaptation to new conditions, which plays the role of a resource for successful self-organization of life and coping with its difficulties during a lockdown.

The study disclosed the regulatory mechanism of successful self-organization of life in a crisis period. It is possible due to the positive contributions of planning, programming, and results evaluation. It is worth noting that the programming of actions has the maximum load. Actually, when long-term planning is impossible, creating programs of actions seems to be an excellent tactical solution. Regulatory flexibility and perseverance are also gaining importance in hard times. These indicators are associated with the ability to quickly restructure one's behavior and activities in changing external/internal conditions and stick to one's guns when difficulties arise due to the circumstances.

The study results have partially confirmed Hypothesis 1, suggesting that SR is positively correlated with successful self-organization of life and negatively with difficulties in the self-organization of life and difficulties in accepting uncertainty. The regulatory process of modeling and the regulatory feature of reliability formed a separate component named the Cito-resource of self-regulation. During periods of increased uncertainty, it is responsible for a 
person's ability to cope with self-organization difficulties and accept uncertainty. Successful self-organization requires a high ability for conscious self-regulation wherein developed modeling of significant conditions and SR reliability play a decisive role. A high level of both these components ensures successful overcoming of the difficulties and suppresses excessive anxiety about life's uncertainty.

We emphasize that the self-organization phenomenon has a complex structure that includes both positive and negative components. Our analysis revealed a component that reflects the difficulties in accepting uncertainty since we deal with the self-organization of life in the new conditions, which is actually a reorganization. Agreeably, the system of conscious self-regulation must adapt, responding to the changes in living conditions, choosing new strategies, for example, according to the Regulatory focus theory (RFT) (Higgins, 1987).

The obtained data on the emotional states caused by the lockdown is consistent with other researchers' findings. Along with self-confidence ("I developed a new daily routine for myself and adhered"), the joy associated with the opportunity to structure one's life differently ("I finally managed to do something for which there was no time and effort before"), most of the identified factors reflect anxiety, a lack of power to confront an imminent danger, and a feeling of depletion of available psychological resources. Researchers note that peoples' answer to imposed selfisolation is often: regrets about missed opportunities, guilt based on one's actions or inaction, shame for helplessness, sadness, and grief for losses. These emotions are accompanied by multiple negative experiences, cognitive assessments (often involuntary), and actions aimed at eliminating uncertainty and related distress (Freeston et al., 2020).

The results obtained in the study show that conscious self-regulation and emotional states make an independent contribution to the self-organization of life during a lockdown. Negative emotional states (negative emotions, emotional exhaustion, helplessness) reinforce the difficulties in the self-organization of life and accepting uncertainty. Thus, Hypothesis 3 suggesting that negative emotional states increase the difficulties of self-organization, while conscious self-regulation helps to overcome them, has been fully confirmed.

On the contrary, optimism contributes to conscious selfregulation, thus indirectly positively influencing the selforganization of life and contributing to solving emerging external and internal problems. In this study, optimism is understood as a positive attitude toward the future (Brissette et al., 2002). Such an attitude promotes the agency and effective activity of the subject and, according to research results, is one of the most important predictors of coping with stress caused by chronic diseases (Carver \& Gaines, 1987). The discovery of such a significant contribution of optimism to the conscious self-regulation is an entirely new result since previously the joint contribution of cognitive and emotional regulation to the goal achievement has not been studied. Hypothesis 2, suggesting that optimism positively contributes to successful selforganization through conscious self-regulation, was confirmed. According to the study results, optimism directly contributes to self-regulation, preventing self-organization difficulties caused by the lockdown rules.

As for the results' practical relevance, we agree with experts who claim that the changes in people's lives during a lockdown have caused them a state of acute stress. In this case, we would refer to space psychology's recommendations because people have been isolated for a long time, which leads to mental exhaustion and a decrease in the accuracy of actions. Our sample manifested itself in a decrease of the regulatory reliability since the survey was carried out after two months of self-isolation and remote study/work. There are recommendations for representatives of extreme professions and athletes, who work in conditions of high uncertainty and mental tension: in case of stress and the accompanying negative experiences, first of all, one should strive to regulate activities, not fixing on the analysis and regulation of emotional states (Dikaya, 2003; Morosanova, 2011). We disagree with psychologists who, in this situation, recommend practicing "mindfulness" techniques that have proven to be highly effective in everyday routine situations (Brown et al., 2012; KabatZinn, 2003; Linehan, 2014). Exercises recommended in the "mindfulness" approach for regulating the emotional and psychophysiological state in a calm habitual environment can be ineffective in challenging situations. As the obtained model showed, self-reflection (the central element of the "mindfulness" techniques) contributes to the difficulties of self-organization and accepting uncertainty, essentially reinforcing their manifestations.

And last but not least, emphasizing the powerful stressful component of self-isolation, which weakens human immunity (Bulgakova, 2011; Vetlugina et al., 2012), we claim that efforts taken in the direction of selfregulation of any activity (educational, professional, sports, communicative, etc.) lead to successful self-organization and reduce stress due to satisfaction with achieved results. High self-regulation and successful self-organization, acting as a resource of stress protection, increase the chances of maintaining peoples' health. At the same time, an optimistic attitude positively affects this system's critical resource-conscious self-regulation. 


\section{Conclusion}

During a lockdown, conscious self-regulation acts as a resource for the self-organization of life. It provides a flexible restructuring of life and activity under the new tasks and conditions. The higher the SR development, the easier it is to cope with difficulties in a situation of uncertainty and prolonged stress.

The regulatory mechanism of successful self-organization of life in a crisis period is disclosed. The processes of planning, programming, evaluating results, and the regulatory features of flexibility and perseverance ensure successful self-organization, prevent difficulties, and help cope with the challenges of accepting uncertainty. Overcoming self-organization difficulties is provided by a high level of the regulatory process of modeling and regulatory reliability feature. In a situation of unpredictability and high anxiety, they act as an autonomous regulatory resource component to ensure successful overcoming life problems and restraining excessive anxiety about uncertainty.

The joint contribution of cognitive and emotional regulation to self-organization was studied for the first time. The data analysis shows that conscious self-regulation and emotional states make an independent contribution to the self-organization of life during a lockdown. Negative states, such as anxiety, emotional exhaustion, and helplessness, reinforce self-organization life difficulties, and accept uncertainty. On the contrary, optimism makes a significant contribution to conscious self-regulation, indirectly positively influencing life self-organization and ensuring the solution of emerging external and internal issues.

It is concluded that a situation of self-isolation can cause acute stress. In this case, to cope with negative emotional states, it is crucial to choose a strategy for regulating one's activity rather than an emotional state. It is recommended to develop a general ability for conscious self-regulation as a meta-resource for solving vital tasks. The best way to do this is to master new types of educational, professional, or sports activities, solve complex non-standard tasks, and obtain a diverse experience beyond the ordinary.

\begin{abstract}
Authors' Contributions I.B. and V.M. were involved in conceptualization; V.M was involved in methodology; I.B was involved in validation; I.B was involved in formal analysis; I.B. was involved in investigation; N.K. was involved in data curation; I.B and V.M. were involved in writing-review and editing; V.M. was involved in supervision; I.B was involved in project Administration.
\end{abstract}

Funding This research received no external funding.

Availability of Data and Material Not applicable
Code Availability Not applicable

\section{Declarations}

Conflicts of Interest The authors declare no conflict of interest.

Ethical Approval The study was conducted in accordance with the Helsinki Declaration. Ethical agreement and consent for access to school were provided by the Psychological Institute of the Russian Academy of Education.

Consent to Participate Verbal consent was obtained from all subjects before the study

Consent for Publication Verbal consent for publication was obtained from all subjects.

\section{References}

Achtziger, A., Gollwitzer, P. M., \& Sheeran, P. (2008). Implementation intentions and shielding goal striving from unwanted thoughts and feelings. Personality and Social Psychology Bulletin, 34, 381-393.

Baumeister, R. F. (1998). The self. In D. T. Gilbert, S. T. Fiske, \& G. Lindzey (Eds.), The handbook of social psychology (pp. 680-740). McGraw-Hill.

Baumeister, R. F., Gailliot, M., DeWall, C. N., \& Oaten, M. (2006). Self-regulation and personality: How interventions increase regulatory success, and how depletion moderates the effects of traits on behavior. Journal of Personality, 74(6), 1773-1802. https://doi.org/10.1111/j.1467-6494.2006.00428.x

Baumeister, R. F., \& Vohs, K. D. (Eds.). (2004). Handbook of selfregulation: Research, theory, and applications. Guilford Press.

Bondarenko, I. N., Morosanova, V. I., Drapkin, I. S., \& Putko, N. A. (2014). Aktualgenez osoznannoy samoregulyatsii v situatsii vybora urovnya slozhnosti uchebnykh zadaniy. [Actual-genesis of conscious self-regulation in the situation of choosing the level of complexity of educational tasks]. Eksperimental'naya psikhologiya [Experimental Psychology], 7(2), 64-81.

Brissette, I., Scheier, M. F., \& Carver, C. S. (2002). The role of optimism in social network development, coping, and psychological adjustment during a life transition. Journal of Personality and Social Psychology, 82(1), 102. https://doi.org/ 10.1037/0022-3514.82.1.102

Brown, K. W., Weinstein, N., \& Creswell, J. D. (2012). Trait mindfulness modulates neuroendocrine and affective responses to social evaluative threat. Psychoneuroendocrinology, 37(12), 2037-2041. https://doi.org/10.1016/j.psyneuen.2012.04.003

Buheji, M., Jahrami, H., \& Dhahi, A. (2020). Minimizing stress exposure during pandemics similar to COVID-19. PBSIJ, 10, 9-16. https://doi.org/10.5923/j.ijpbs.20201001.02

Bulgakova, O. S. (2011). Immunitet i razlichnyye stadii stressornogo vozdeystviya [Immunity and various stages of stress exposure]. Uspekhi sovremennogo yestestvoznaniya [Successes of Modern Natural Science], 4, 31-35.

Carver, C. S., \& Gaines, J. G. (1987). Optimism, pessimism, and postpartum depression. Cognitive Therapy and Research, 11(4), 449-462. https://doi.org/10.1007/BF01175355

Carver, C. S., \& Scheier, M. F. (1990). Origins and functions of positive and negative affect: A control-process view. Psychological Review, 97, 19-35.

Dikaya, L. G. (2003). Psikhicheskaya samoregulyatsiya funktsional'nogo sostoyaniya cheloveka (sistemno-deyatel'nostnyi podkhod) [Mental self-regulation of a person's functional state 
(system-activity approach)] (pp. 86-109). Institute of Psychology of RAS.

Fomina, T. G., \& Morosanova, V. I. (2017). Self-regulation, maths self-efficacy, maths interest and mathematics achievement. New Trends and Issues Proceedings on Humanities and Social Science, 4(6), 33-40. https://doi.org/10.18844/prosoc.v4i6.2909

Freeston, M., Tiplady, A., Mawn, L., Bottesi, G., \& Thwaites, S. (2020). Towards a model of uncertainty distress in the context of Coronavirus (Covid-19). The Cognitive Behaviour Therapist. https://doi.org/10.1017/S1754470X2000029X

Gallo, I. S., Keil, A., McCulloch, K. C., Rockstroh, B., \& Gollwitzer, P. M. (2009). Strategic automation of emotion regulation. Journal of Personality and Social Psychology, 96(1), 11-31.

Garnefski, N., Legerstee, J., Kraaij, V., van Den Kommer, T., \& Teerds, J. A. N. (2002). Cognitive coping strategies and symptoms of depression and anxiety: A comparison between adolescents and adults. Journal of Adolescence, 25(6), 603-611. https://doi.org/10.1006/jado.2002.0507

Gross, J. J. (2015). Emotion regulation: Current status and future prospects. Psychological Inquiry, 26, 1-26.

Gross, J. J., \& Jazaieri, H. (2014). Emotion, emotion regulation, and psychopathology: An affective science perspective. Clinical Psychological Science, 2(4), 387-401. https://doi.org/10.117 7/2167702614536164

Gross, J. J., \& John, O. P. (2003). Individual differences in two emotion regulation processes: Implications for affect, relationships, and well-being. Journal of Personality and Social Psychology, $\quad 85(2), \quad 348-362 . \quad$ https://doi.org/10.1037/00 22-3514.85.2.348

Grund, A., \& Carstens, C. A. (2019). Self-control motivationally reconsidered:"Acting" self-controlled is different to "being good" at self-control. Motivation and Emotion, 43(1), 63-81. https://doi.org/10.1007/s11031-018-9721-3

Guan, W.-J., Ni, Z.-Y., Hu, Y., Liang, W.-H., Ou, C.-Q., He, J.-X., et al. (2020). Clinical characteristics of coronavirus disease 2019 in China. New England journal of medicine, 382(18), $1708-1720$.

Higgins, E. T. (1987). Self-discrepancy: A theory relating self and affect. Psychological Review, 94, 319-340.

Hoyle, R. H. (2006). Personality and Self-Regulation: Trait and Information-Processing Perspectives. Journal of Personality, 74(6), 1507-1525. https://doi.org/10.1111/j.1467-6494.2006. 00418.x

Kabat-Zinn, J. (2003). Mindfulness-based interventions in context: past, present, and future. Clinical psychology: Science and Practice, 10(2), 144-156. https://doi.org/10.1093/clipsy.bpg016

Koole, S. L., Webb, T. L., \& Sheeran, P. L. (2015). Implicit emotion regulation: Feeling better without knowing why. Current Opinion in Psychology, 3, 6-10.

Kostromina , S. N. (2010). Strukturno-funktsional'naya model' samoorganizatsii deyatel'nosti [Structural and functional model of self-organization of activity]. Vestnik Sankt-Peterburgskogo universiteta. Sotsiologiya [Buletin of St. Petersburg University. Sociology], 4, 153-161.

Kuhnle, C., Hofer, M., \& Kilian, B. (2010). The relationship of value orientations, self-control, frequency of school-leisure conflicts, and life-balance in adolescence. Learning and Individual Differences, 20(3), 251-255. https://doi.org/10.1016/j.lind if.2010.02.003

Kuhnle, C., Hofer, M., \& Kilian, B. (2012). Self-control as predictor of school grades, life balance, and flow in adolescents. British Journal of Educational Psychology, 82(4), 533-548. https://doi.org/10.1111/j.2044-8279.2011.02042.x

Kumar, A., \& Somani, A. (2020). Dealing with Corona virus anxiety and OCD. Asian Journal of Psychiatry, 51, 102053. https://doi.org/10.1016/j.ajp.2020.102053
Lewis, M. D., \& Granic, I. (Eds.). (2000). Cambridge studies in social and emotional development. Emotion, development, and selforganization: Dynamic systems approaches to emotional development. Cambridge University Press. https://doi.org/ 10.1017/CBO9780511527883

Linehan, M. M. (2014). DBT? Skills training handouts and worksheets. Guilford Publications.

Lyusin, D. V., \& Ushakov, D. V. (Eds.). (2009). Socialniy $i$ emocionalniy intellect: Ot processov $k$ izmereniyam [Social and emotional intelligence: From processes to measures]. Institute of Psychology, Russian Academy of Sciences Publ.

Maslach, C., \& Jackson, S. E. (1981). The measurement of experienced burnout. Journal of Occupational Behavior, 2, 99-113. https://doi.org/10.1002/job.4030020205

Mayer, J. D., Salovey, P., \& Caruso, D. R. (2008). Emotional intelligence: New ability or eclectic traits?. American Psychologist, 63(6), 503. https://doi.org/10.1037/0003-066X.63.6.503

Montemurro, N. (2020). The emotional impact of COVID-19: From medical staff to common people. Brain, behavior, and immunity, 87, 23-24. https://doi.org/10.1016/j.bbi.2020.03.032

Morosanova, V. I. (2011). Razvitiye teorii osoznannoy samoregulyatsii: differentsial'nyy podkhod [Development of a theory of conscious self-regulation: A differential approach]. Voprosy psikhologii [Issues in psychology], 3, 132-144.

Morosanova, V. I. (2014). Osoznannaya samoregulyatsiya proizvol'noy aktivnosti cheloveka kak psikhologicheskiy resurs dostizheniya tseley [Conscious self-regulation of the human's voluntary activity as a psychological resource of goals achievement]. Teoreticheskaya i eksperimental'naya psikhologiya [Theoretical and Experimental Psychology], 7(4), 62-78.

Morosanova, V. I. (2017). Osoznannaya samoregulyatsiya kak metasistema psikhologicheskikh resursov dostizheniya tseley $\mathrm{i}$ samorazvitiya cheloveka [Conscious self-regulation as a metasystem of psychological resources for achieving goals and human self-development]. Fundamental'nyye $i$ prikladnyye issledovaniya sovremennoy psikhologii: rezul'taty i perspektivy razvitiya [Fundamental and applied research in modern psychology: results and development prospects]/Ed. by A. L. Zhuravlev, $V$. A. Koltsova. Moscow: Institute of Psychology RAS (pp. 501-509).

Morosanova, V.I. (2020). Osoznannaya samoregulyatsiya kak metaresurs dostizheniya tseley i obsuzhdeniya problem zhiznedeyatel'nosti [Conscious self-regulation as a meta-resource for achieving goals and discussing the problems of life]. Voprosy psikhologii [Issues in psychology], 3.

Morosanova, V. I., \& Filippova, E. V. (2019). Ot chego zavisit nadezhnost' deystviy uchashchikhsya na ekzamene [What ensures reliability of a student's actions in an examination]. Voprosy psikhologii [Issues in psychology], 1, 65-78.

Morosanova, V. I., \& Kondratyuk, N. G. (2020). Oprosnik V.I. Morosanovoj «Stil' samoregulyacii povedeniya - SSPM 2020» [V.I. Morosanova's "Self-regulation profile questionnaire SRPQM 2020]". Voprosy psihologii [Questions of psychology]. 4, pp. $155-167$.

Morosanova, V. I., Fomina, T. G., Kovas, Y. V., \& Bogdanova, O. E. (2016). Cognitive and regulatory characteristics and mathematical performance in high school students. Personality and Individual Differences, 90, 177-186.

Morosanova, V. I., Kondratyuk, N. G., \& Gaidamashko, I. V. (2020). Nadezhnost' osoznannoy samoregulyatsii kak resurs dostizheniya tseley $\mathrm{v}$ professiyakh vysokogo riska [The reliability of conscious self-regulation as a resource for achieving goals in high-risk professions]. Vestnik Moskovskogo universiteta. Seriya 14. Psikhologiya [Moscow University Bulletin. Series 14. Psychology], (1), 77-95. 
Ochsner, K. N., \& Gross, J. J. (2005). The cognitive control of emotion. Trends in Cognitive Sciences, 9, 242-249.

Peng, M., Mo, B., Liu, Y., Xu, M., Song, X., Liu, L., Fang, Y., Guo, T., Ye, J., Yu, Z., Deng, Q., \& Zhang, X. (2020). Prevalence, risk factors and clinical correlates of depression in quarantined population during the COVID-19 outbreak. Journal of Affective Disorders. https://doi.org/10.1016/j.jad.2020.06.035

Puustinen, M., \& Pulkkinen, L. (2001). Models of self-regulated learning: A review. Scandinavian Journal of Educational Research, 45(3), 269-286. https://doi.org/10.1080/0031 3830120074206

Sheppes, G., \& Gross, J. J. (2011). Is timing everything? Temporal considerations in emotion regulation. Personality and Social Psychology Review, 15(4), 319-31.
Vetlugina, T. P., Nikitina, V. B., Nevidimova, T. I., Lobacheva, O. A., Batukhtina, E. I., Stoyanova, I. Y., \& Semke, V. Y. (2012). The system of immunity and the level of anxiety under person adaption to the new conditions of life. Fundamental research, $1(9), 17-21$.

Vodopyanova, N. E., \& Starchenkova, E. S. (2008). Sindrom vygoraniya [Burnout syndrome]. St. Petersburg: Piter.

Zimmerman, B. J., \& Schunk, D. H. (Eds.). (2001). Self-regulated learning and academic achievement: Theoretical perspectives (2nd ed.). Erlbaum.

Publisher's Note Springer Nature remains neutral with regard to jurisdictional claims in published maps and institutional affiliations. 